\title{
Integrated pharmacokinetics/pharmacodynamics parameters-based dosing guidelines of enrofloxacin in grass carp Ctenopharyngodon idella to minimize selection of drug resistance
}

\author{
Lijuan Xu, Hao Wang, Xianle Yang and Liqun Lu
}

\begin{abstract}
Background: Antibiotic resistance has become a serious global problem and is steadily increasing worldwide in almost every bacterial species treated with antibiotics. In aquaculture, the therapeutic options for the treatment of A. hydrophila infection were only limited to several antibiotics, which contributed for the fast-speed emergence of drug tolerance. Accordingly, the aim of this study was to establish a medication regimen to prevent drug resistant bacteria. To determine a rational therapeutic guideline, integrated pharmacodynamics and pharmacokinetics parameters were based to predict dose and dosage interval of enrofloxacin in grass carp Ctenopharyngodon idella infected by a field-isolated $A$. hydrophila strain.
\end{abstract}

Results: The pathogenic A. hydrophila strain (AH10) in grass carp was identified and found to be sensitive to enrofloxacin. The mutant selection window (MSW) of enrofloxacin on isolate AH10 was determined to be $0.5-3$ $\mu \mathrm{g} / \mathrm{mL}$ based on the mutant prevention concentration (MPC) and minimum inhibitory concentration (MIC) value. By using high-performance liquid chromatography (HPLC) system, the Pharmacokinetic (PK) parameters of enrofloxacin and its metabolite ciprofloxacin in grass carp were monitored after a single oral gavage of 10, 20, 30 $\mu \mathrm{g}$ enrofloxacin per $\mathrm{g}$ body weight. Dosing of $30 \mu \mathrm{g} / \mathrm{g}$ resulted in serum maximum concentration $\left(C_{\max }\right)$ of 7.151 $\mathrm{\mu g} / \mathrm{mL}$, and concentration in serum was above MPC till $24 \mathrm{~h}$ post the single dose. Once-daily dosing of $30 \mathrm{\mu g} / \mathrm{g}$ was determined to be the rational choice for controlling AH10 infection and preventing mutant selection in grass carp. Data of mean residue time (MRT) and body clearance (CLz) indicated that both enrofloxacin and its metabolite ciprofloxacin present similar eliminating rate and pattern in serum, muscle and liver. A withdraw time of more than $32 \mathrm{~d}$ was suggested based on the drug eliminating rate and pharmacokinetic model described by a polyexponential equation.

Conclusions: Based on integrated PK/PD parameters (AUC/MIC, Cmax/MIC, and T>MPC), the results of this study established a principle, for the first time, on drawing accurate dosing guideline for pharmacotherapy against $A$. hydrophila strain (AH10) for prevention of drug-resistant mutants. Our approach in combining PK data with PD parameters (including MPC and MSW) was the new effort in aquaculture to face the challenge of drug resistance by drawing a specific dosage guideline of antibiotics.

Keywords: Enrofloxacin, Grass carp ctenopharyngodon idella, Pharmacokinetics, Pharmacodynamics, Aeromonas hydrophila

\footnotetext{
* Correspondence: lqlv@shou.edu.cn

Key Laboratory of Freshwater Fishery Germplasm Resources, Ministry of

Agriculture, Shanghai Ocean University, Shanghai 201306, People's Republic

of China
} 


\section{Background}

Fluoroquinolones such as enrofloxacin and ciprofloxacin are widely used in the treatment of animal disease caused by both Gram-negative and Gram-positive bacteria [1]. The bactericidal activity of fluoroquinolones is concentration-dependent, thus the peak level $\left(\mathrm{C}_{\max }\right)$ and the amount of drug, as reflected by the area under the concentration-versus-time curve (AUC) in serum, are important predictors of the efficacy of fluoroquinolones [2]. Enrofloxacin, a fluoroquinolone carboxylic derivative, is Food and Drug Administration (FDA)-approved for treatment of individual pets and domestic animals in the United States. Enrofloxacin can be de-ethylated in vivo to its metabolite ciprofloxacin with a rate that is species-specific [3]. Aeromonas hydrophila (A. hydrophila) is a ubiquitous Gram-negative bacterium causing fatal hemorrhagic septicemia and dropsy in many commercially important freshwater fish worldwide [4].

A. hydrophila is also considered one of the major pathogens threatening the freshwater fish cultivation industry including grass carp ctenopharyngodon idella, the top aquaculture species of China [5]. Despite the severe economic loss, no vaccination against $A$. hydrophila infection has been commercially applied in China [6]. The main reason for the lack of commercial vaccines might be the existence of antigenic heterogeneity of various $A$. hydrophila strains in the field. Until now, antibacterial drugs through oral delivery are the popular and effective choice for the control of pandemics causing by $A$. hydrophila. In China, enrofloxacin is one of the effective antimicrobials in grass carp farms and has been widely applied in fish ponds nationwide for over 10 years [7].

Antibiotic resistance has become a serious global problem and is steadily increasing worldwide in almost every bacterial species treated with antibiotics [8]. In aquaculture, the therapeutic options for the treatment of $A$. hydrophila infection were only limited to several antibiotics, which contributed for the fast-speed emergence of drug tolerance [9]. Traditional one-for-all dosing guideline of enrofloxacin is not applicable any more. The failure to control bacterial disease in fish with antibiotics was most likely to result from sub-optimal therapy, irrespective of the degree of resistance. Enrofloxacin oral formulations have been commercialized in China. Farmers can use it to feed fish to treat bacterial infection. In fact, more and more pandemic $A$. hydrophila strains isolated from the diseased fish were with reduced susceptibility to enrofloxacin [10]. Given this, there is an urgent need to develop a medication regimen that prevents the formation of drug resistant bacteria.

Recently, new approaches were tested with an aim to increase efficacy of antibacterial drugs and to reduce resistance selection. It is well established that serum $\mathrm{C}_{\text {max }} / \mathrm{MIC}$ (ratio of maximum drug concentration to minimum inhibitory concentration) $>8$ and AUC/MIC (ratio of area under the concentration-time curve to minimum inhibitory concentration) $>100$ are required for efficient and optimal pharmacotherapy of enrofloxacin [11]. The mutant prevention concentration (MPC) is a new concept meant to face the increased prevalence of antibiotic resistance by using antibiotic concentrations able to prevent the selection of resistant bacteria populations [12]. Since $\mathrm{T}>\mathrm{MPC}$, exposure time of drug concentration above MPC, served as a more important factor in preventing drug resistance, $\mathrm{AUC} / \mathrm{MIC}, \mathrm{C}_{\max } / \mathrm{MIC}$ and $\mathrm{T}>\mathrm{MPC}$ were important integrated $\mathrm{PK} / \mathrm{PD}$ parameters.

The aim of the present study was to develop a medication regimen against a disease caused by $A$. hydrophila strain (AH10) in grass carp by integrating pharmacodynamic (including MPC and MSW) and pharmacokinetic parameters for enrofloxacin. Although enrofloxacin is widely used as antimicrobial agent, its $\mathrm{PK}$ or PD parameters in grass carp are lacking. $10 \sim 30 \mu \mathrm{g} / \mathrm{g}$ is the dose of recommended in the industry [13]. To clarify the PK indices, oral dosing of 10,20 , and $30 \mu \mathrm{g} / \mathrm{g}$ body weight were individually examined in the study. The results of this study paved the way for establishing dosing guidelines to avoid selecting resistant mutants of specific fish bacterial pathogen with uncertain drug-susceptibility.

\section{Results and discussion}

The median lethal dose $\left(\mathrm{LD}_{50}\right)$ of $A$. hydrophila (AH10) on grass carp

A. hydrophila was the most destructive bacterial pathogen of farmed grass carp. AH10 strain was isolated and identified according to the method of Roxana et al. [14] from diseased grass carp in 2011 (NCBI accession number: JX413114.1). The pathogen was stored in National Aquatic Pathogen Collection Center (No. 2011AH10). Grass carp was susceptible to laboratory infection with isolate AH10. External clinical signs of the infection included haemorrhaging and erratic swimming behavior. The seven day $\mathrm{LD}_{50}$ for grass carp by intraperitoneal route was $1.18 \times 10^{6} \mathrm{CFU} / \mathrm{mL}$ (the $95 \%$ confidence interval was $5.53 \times 10^{5} \sim 2.42 \times 10^{6} \mathrm{CFU} / \mathrm{mL}$ ), which was analyzed from the data in Table 1 by SPSS 16.0 software. Based on the clinical symptom and values of $\mathrm{LD}_{50}$, isolate $\mathrm{AH} 10$ should be regarded as a virulent strain.

\section{Activities of enrofloxacin on A. hydrophila $(\mathrm{AH} 10)$ in vitro}

The in vitro activities of enrofloxacin on isolate AH10 were subsequently investigated. The MIC value of enrofloxacin on isolate AH10 was $0.5 \mu \mathrm{g} / \mathrm{mL}$, and that of quality control strain A. hydrophila ATCC 7966 was $0.25 \mu \mathrm{g} / \mathrm{mL}$. The isolate $\mathrm{AH} 10$ was less sensitive to enrofloxacin than control strain ATCC7966. MPC values should be considered in drawing dosing strategies since traditional MIC-based dosing level might give rise to treatment failure due 
Table 1 Infection of grass carp with $\mathrm{AH} 10$ by intraperitoneal route

\begin{tabular}{ccccccccccc}
\hline $\begin{array}{c}\text { Pathogen } \\
\text { amount } \\
\text { (CFU/mL) }\end{array}$ & $\begin{array}{c}\text { Fish } \\
\text { amount }\end{array}$ & \multicolumn{6}{c}{ Dead number of fish } & $\begin{array}{c}\text { Accumulated } \\
\text { dead number }\end{array}$ \\
\hline $2.5 \times 10^{3}$ & 10 & 0 & 0 & 0 & 0 & 0 & 0 & 0 & 0 \\
$2.5 \times 10^{4}$ & 10 & 0 & 0 & 1 & 1 & 0 & 0 & 0 & 2 \\
$2.5 \times 10^{5}$ & 10 & 1 & 2 & 1 & 1 & 0 & 0 & 0 & 5 \\
$2.5 \times 10^{6}$ & 10 & 2 & 3 & 1 & 2 & 0 & 0 & 0 & 8 \\
$2.5 \times 10^{7}$ & 10 & 5 & 3 & 2 & & & & & 10 \\
$2.5 \times 10^{8}$ & 10 & 10 & & & & & & & \\
\hline
\end{tabular}

to the selection of drug-resistant mutant. The MPC of enrofloxacin on isolate $\mathrm{AH} 10$ was determined to be $6 \mathrm{MIC}(3 \mu \mathrm{g} / \mathrm{mL})$, which was above the resistance breakpoint for enrofloxacin $(\geq 2 \mu \mathrm{g} / \mathrm{mL})$. The MSW of enrofloxacin on isolate $\mathrm{AH} 10$ was determined to be $0.5-3.0 \mu \mathrm{g} / \mathrm{mL}$, which reflected the difference between the measured MIC and MPC values. Existence of the MSW allowed us to predict the likelihood for resistance selection or prevention based on achievable and therapeutic drug concentrations [15]. Selective amplification of the non-susceptible AH10 population was expected to occur in the identified MSW of enrofloxacin. As far as we knew, this was the first study trying to apply MPC principles to optimize therapy and reduce resistance selection of fish bacterial pathogen.

The post antibiotic effect (PAE) may contribute to the in vivo efficacy of enrofloxacin [16]. It was well known that enrofloxacin prevented the synthesis of bacterial DNA by gyrase, the PAE might represent the time for it to dissociate from the receptor binding sites and to diffuse out of the bacterium. It was generally believed that PAE was concentration dependent and directly related to the exposure time [17]. In this study, PAE of enrofloxacin was evaluated by exposure of isolate AH10 to it at 2, 4, and 8 times MIC for $1 \mathrm{~h}$ (Figure. 1). The PAE of enrofloxacin was $1.44 \pm 0.36 \mathrm{~h}, 1.57 \pm 0.09 \mathrm{~h}, 1.83 \pm 0.21 \mathrm{~h}$, respectively. The data predicted that the dosing interval deduced from the time-concentration PK curve could be $1-2 \mathrm{~h}$ longer due to the existence of PAE. Although the in vivo PAE of enrofloxacin was still awaiting further investigation, our data at least suggested that the T>MPC seemed to be the dominant factor in drawing dose intervals since PAE of enrofloxacin was comparably short.

\section{Pharmacokinetics of enrofloxacin in grass carp}

HPLC presents a simple, rapid, and reliable analytical method for detection and quantification of enrofloxacin and its metabolite ciprofloxacin. In our HPLC system, the limit of detection (LOD) for enrofloxacin and ciprofloxacin was $0.02 \mu \mathrm{g} / \mathrm{mL}$ and $0.004 \mu \mathrm{g} / \mathrm{mL}$, respectively. The sample concentration was calculated by comparison of its

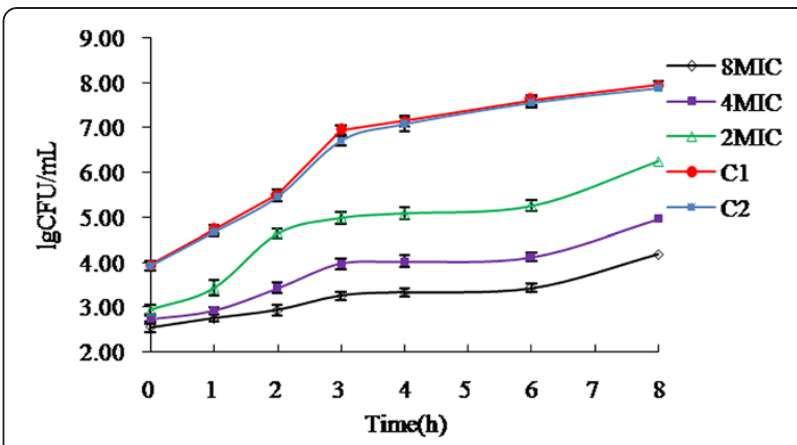

Figure 1 Replication of isolate $\mathrm{AH} 10$ after $1 \mathrm{~h}$ exposure to enrofloxacin at indicated concentration. Control groups ( $\mathrm{C} 1$ and C2) referred to bacterial without drug treatment. ( $n=3$, The mean $\pm S D$ ). After $1 \mathrm{~h}$ exposure to enrofloxacin with a concentration as indicated in the figure, the concentration of isolate $\mathrm{AH} 10$ was determined to be $8.71 \times 10^{3} \mathrm{CFU} / \mathrm{mL}(\mathrm{C} 1), 8.51 \times 10^{3} \mathrm{CFU} / \mathrm{mL}(\mathrm{C} 2), 8.71 \times 10^{2} \mathrm{CFU} / \mathrm{mL}$ $(2 \mathrm{MIC}), 5.50 \times 10^{2} \mathrm{CFU} / \mathrm{mL}(4 \mathrm{MIC})$ and $3.63 \times 10^{2} \mathrm{CFU} / \mathrm{mL}$ (8MIC), respectively.

peak area with the peak area of a nominal concentration of an external standard. The chromatography area and the concentration of enrofloxacin and ciprofloxacin showed a linear relationship. The standard curve equation of enrofloxacin is $y=191.7 x-52.68(r=0.9995)$, and the standard curve equation of ciprofloxacin is $y=92.74 \times-$ $12.00(\mathrm{r}=0.9999)$. The standard was routinely corrected by the concentration factor and the recovery rate [18]. The linearity of our method was confirmed using the classical tests by analysis of variance.

The concentration-time profiles of serum and tissue after an oral dose of $10 \mu \mathrm{g} / \mathrm{g}, 20 \mu \mathrm{g} / \mathrm{g}$, and $30 \mu \mathrm{g} / \mathrm{g}$ were separately shown in Figure 2. In general, high dose $(20 \mu \mathrm{g} / \mathrm{g}$ and $30 \mu \mathrm{g} / \mathrm{g})$ resulted in a shorter time $(0.5 \mathrm{~h})$ to peak level than lower dose $(1 \mathrm{~h}$ for dose of $10 \mu \mathrm{g} / \mathrm{g})$, and the time to reach the peak level in muscle $(\geq 10 \mathrm{~h})$ was much longer than serum \& other tissues for all the three doses. $24 \mathrm{~h}$ post drug delivery, serum concentration of enrofloxacin was $0.801 \mu \mathrm{g} / \mathrm{mL}$, $1.918 \mu \mathrm{g} / \mathrm{mL}$, and $2.953 \mu \mathrm{g} / \mathrm{mL}$, respectively. The low elimination rate generally predicted a positive clinical result and correlated with the extensive application of enrofloxacin in controlling bacterial disease in grass carp. Peak levels $\left(\mathrm{C}_{\max }\right)$ of liver $(8.941 \mu \mathrm{g} / \mathrm{g}, 18.344 \mu \mathrm{g} / \mathrm{g}$, and $20.076 \mu \mathrm{g} / \mathrm{g}$, respectively) was the highest, followed by kidney $(3.362 \mu \mathrm{g} / \mathrm{g}, 8.152 \mu \mathrm{g} / \mathrm{g}$, and $9.587 \mu \mathrm{g} / \mathrm{g})$, serum $(2.837 \mu \mathrm{g} / \mathrm{g}, 5.685 \mu \mathrm{g} / \mathrm{g}$, and $7.150 \mu \mathrm{g} / \mathrm{g})$, and muscle $(1.320 \mu \mathrm{g} / \mathrm{g}, 2.369 \mu \mathrm{g} / \mathrm{g}$, and $2.628 \mu \mathrm{g} / \mathrm{g})$. These data were basically in consistence with PK parameters of enrofloxacin in other fish species [19].

All the data were analysed by Kinetica4.4, the results showed that it was a two-compartment model with zero absorption in serum, liver and kidney, a two-compartment model with first-order absorption in muscle (Table 2). The 

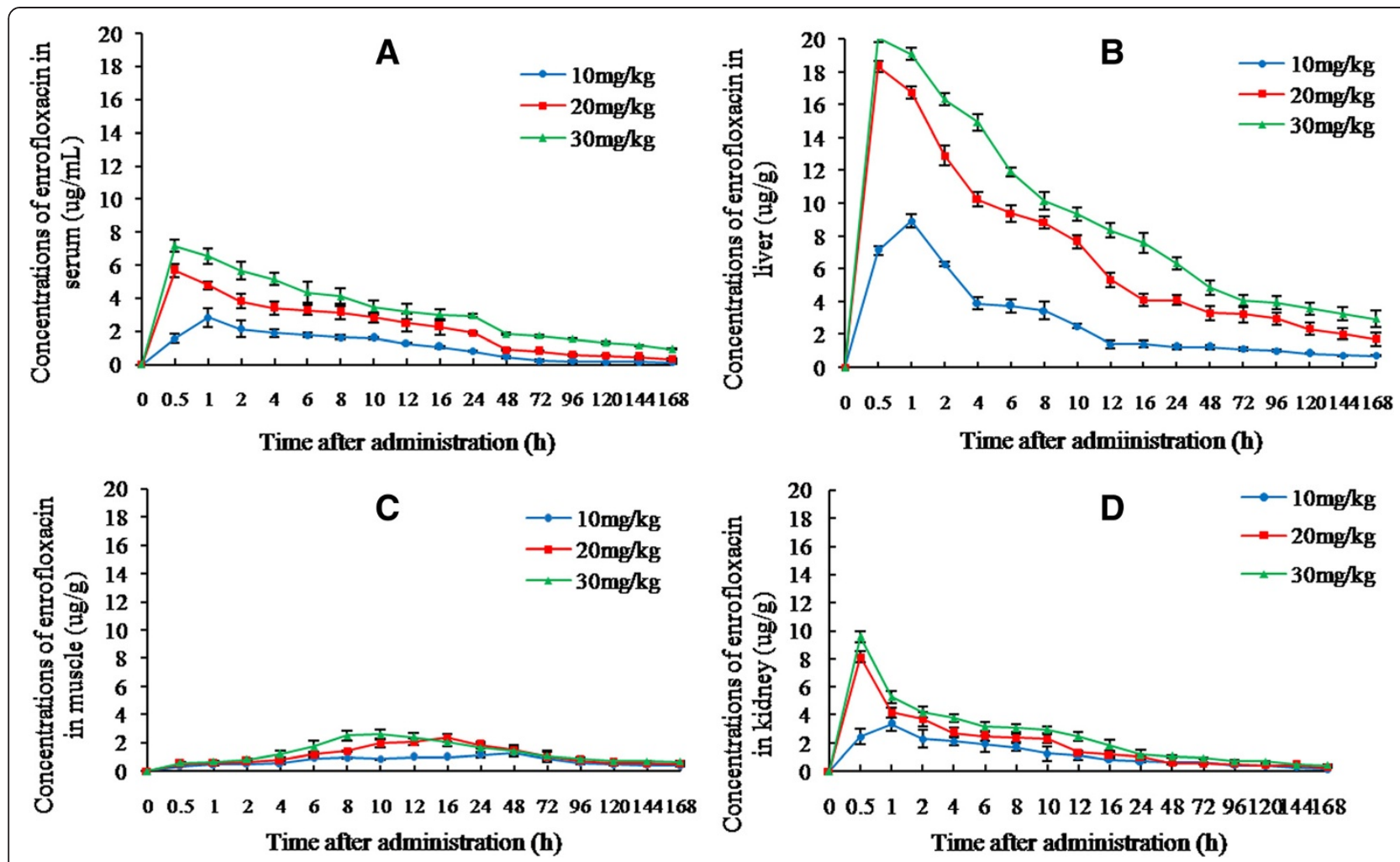

Figure 2 Enrofloxacin concentration-time curves in serum and tissues of grass carp at different administration doses. Standard deviation is given at vertical bars $\left(n=5\right.$, The mean $\pm S D$ ). At three doses of enrofloxacin, the $C_{\max }$ of enrofloxacin in liver is highest and the $C_{\max }$ of enrofloxacin in muscle is lowest. The time to $C_{\max }$ in muscle for enrofloxacin was significantly longer than in serum and other tissues. (A: Serum; $\mathbf{B}$ : Liver; $\mathbf{C}$ : Muscle $\mathbf{D}$ : Kidney).

correlation coefficient exceeded 0.99 and high model criteria ( $>5)$ were obtained. Listed PK parameters were demonstrated in Table 3. It was worth to note that model-independent parameters such as elimination half-life $\left(t_{1 / 2}\right)$, area under the curve (AUC), and clearance

Table 2 Best concentration-time equations of enrofloxacin in grass carp

\begin{tabular}{|c|c|c|}
\hline Dose & Tissues & Equation \\
\hline \multirow{4}{*}{$10 \mu \mathrm{g} / \mathrm{g}$} & Serum & $C=0.844 e^{-0.114 t}+0.500 e^{-0.016 t}$ \\
\hline & Liver & $C=3.007 e^{-0.087 t}+1.634 e^{-0.005 t}$ \\
\hline & Muscel & $C=3.334 e^{-0.022 t}+1.025 e^{-0.159 t}-4.359 e^{-0.2656 t}$ \\
\hline & Kidney & $C=1.109 e^{-0.027 t}+0.164 e^{-0.025 t}$ \\
\hline \multirow{4}{*}{$20 \mu \mathrm{g} / \mathrm{g}$} & Serum & $C=1.707 e^{-0.166 t}+1.600 e^{-0.015 t}$ \\
\hline & Liver & $C=9.072 e^{-0.191 t}+4.631 e^{-0.015 t}$ \\
\hline & Muscel & $C=4.630 e^{-0.055 t}+0.758 e^{-0.003 t}-5.388 e^{-0.216 t}$ \\
\hline & Kidney & $C=7.39859 e^{-0.0244547 t}+4.01081 e^{-0.0626125 t}$ \\
\hline \multirow{4}{*}{$30 \mu \mathrm{g} / \mathrm{g}$} & Serum & $C=3.904 e^{-0.164 t}+3.013 e^{-0.007 t}$ \\
\hline & Liver & $C=14.577 e^{-0.066 t}+5.887 e^{-0.004 t}$ \\
\hline & Muscel & $C=2.269 e^{-0.066 t}+1.365 e^{-0.005 t}-3.634 e^{-0.211 t}$ \\
\hline & Kidney & $C=6.154 \mathrm{e}^{-0.044 t}+4.044 \mathrm{e}^{-0.036 \mathrm{t}}$ \\
\hline
\end{tabular}

(CLs) were calculated for each of the five fish and averaged in the table.

The serum concentration was the key factor for drug effectivity. At the tested oral dose of $10 \mu \mathrm{g} / \mathrm{g}, 20 \mu \mathrm{g} / \mathrm{g}$ and $30 \mu \mathrm{g} / \mathrm{g}$ in three independent experiments, the distribution half life $\left(\mathrm{T}_{1 / 2 \alpha}\right)$ of enrofloxacin in serum was $6.098 \mathrm{~h}$, $4.186 \mathrm{~h}$, and $4.348 \mathrm{~h}$, respectively. AUC of enrofloxacin in serum was $72.538 \mu \mathrm{g} / \mathrm{mL} \cdot \mathrm{h}, 171.984 \mu \mathrm{g} / \mathrm{mL} \cdot \mathrm{h}$, and $318.187 \mu \mathrm{g} / \mathrm{mL} \cdot \mathrm{h}$, respectively. These data suggested that higher dose resulted in significant higher AUC value or clinical result than lower dose, but with a similar absorption rate. The muscle concentration might be important in deciding the withdrawal time. The terminal (elimination) half life $\left(\mathrm{T}_{1 / 2 \beta}\right)$ of enrofloxacin in muscle was $95.070 \mathrm{~h}, 150.884 \mathrm{~h}$, and $161.381 \mathrm{~h}$, respectively. The AUC value of enrofloxacin in muscle was $129.154 \mu \mathrm{g} / \mathrm{mL} \cdot \mathrm{h}, 175.160 \mu \mathrm{g} / \mathrm{mL} \cdot \mathrm{h}$, and $188.914 \mu \mathrm{g} / \mathrm{mL} \cdot \mathrm{h}$, respectively. These results implied that the elimination rate in muscle was low and seemed independent of the dose level at higher dose $(20 \mu \mathrm{g} / \mathrm{g}$ and $30 \mu \mathrm{g} / \mathrm{g})$, and the similar AUC value of the two dosal levels further suggested that the withdrawal time might be similar, which was ideal for disease and drug-residual control since better clinical result might be achieved by increasing the dose level while keeping a similar withdrawal time. 
Table 3 PK parameters of enrofloxacin in grass carp $(n=5)$

\begin{tabular}{|c|c|c|c|c|c|c|c|c|c|c|c|c|}
\hline \multirow{3}{*}{$\begin{array}{c}\text { Tissues } \\
\text { Parameters }\end{array}$} & \multicolumn{12}{|c|}{ Dose } \\
\hline & \multicolumn{4}{|c|}{$10 \mathrm{mg} / \mathrm{kg}$} & \multicolumn{4}{|c|}{$20 \mathrm{mg} / \mathrm{kg}$} & \multicolumn{4}{|c|}{$30 \mathrm{mg} / \mathrm{kg}$} \\
\hline & Serum & Liver & Muscle & Kidney & Serum & Liver & Muscle & Kidney & Serum & Liver & Muscle & Kidney \\
\hline $\mathrm{A}(\mu \mathrm{g} / \mathrm{mL})$ & 0.844 & 3.007 & 3.334 & 1.109 & 1.707 & 9.072 & 4.630 & 7.162 & 3.904 & 14.577 & 2.269 & 6.154 \\
\hline $\mathrm{B}(\mu \mathrm{g} / \mathrm{mL})$ & 0.500 & 1.634 & 1.025 & 0.164 & 1.6 & 4.631 & 0.758 & 3.682 & 3.013 & 5.887 & 1.365 & 4.044 \\
\hline$A(/ h)$ & 0.114 & 0.087 & 0.022 & 0.027 & 0.166 & 0.191 & 0.055 & 0.024 & 0.164 & 0.068 & 0.066 & 0.044 \\
\hline$B(/ h)$ & 0.016 & 0.005 & 0.159 & 0.025 & 0.015 & 0.015 & 0.003 & 0.063 & 0.007 & 0.004 & 0.005 & 0.036 \\
\hline $\mathrm{Ka}(/ \mathrm{h})$ & 0.491 & 0.275 & 0.266 & 0.478 & 0.671 & 1.787 & 0.216 & 0.764 & 0.502 & 1.445 & 0.211 & 0.676 \\
\hline Kel(/h) & 0.037 & 0.020 & 0.013 & 0.027 & 0.024 & 0.019 & 0.160 & 0.024 & 0.015 & 0.013 & 0.143 & 0.024 \\
\hline$T_{1 / 2 a}(h)$ & 6.098 & 0.080 & 3.126 & 25.938 & 4.186 & 36.262 & 12.595 & 28.344 & 4.348 & 10.145 & 10.515 & 27.775 \\
\hline$T_{1 / 2 \beta}(h)$ & 42.728 & 86.253 & 95.070 & 42.375 & 46.757 & 110.452 & 150.884 & 107.861 & 97.363 & 184.996 & 161.381 & 124.271 \\
\hline $\operatorname{Tmax}(\mathrm{h})$ & 1.000 & 1.000 & 48.000 & 1.000 & 0.500 & 0.500 & 16.000 & 0.500 & 0.500 & 0.500 & 10.000 & 0.500 \\
\hline$M R T_{0-t}(h)$ & 44.566 & 62.765 & 63.938 & 55.871 & 51.841 & 63.093 & 67.096 & 56.620 & 144.573 & 65.005 & 68.159 & 56.620 \\
\hline$C \max (\mu \mathrm{g} / \mathrm{mL})$ & 2.837 & 8.941 & 1.320 & 3.362 & 5.685 & 18.344 & 2.369 & 8.152 & 7.151 & 20.076 & 2.628 & 9.587 \\
\hline $\mathrm{AUC}_{24}(\mu \mathrm{g} / \mathrm{mL} \cdot \mathrm{h})$ & 25.838 & 66.108 & 21.683 & 33.183 & 67.585 & 114.168 & 40.349 & 49.589 & 90.486 & 242.313 & 44.666 & 66.359 \\
\hline AUC ( $\mu \mathrm{g} / \mathrm{mL} \cdot h)$ & 72.538 & 210.118 & 129.154 & 102.899 & 171.984 & 338.316 & 175.160 & 127.511 & 318.187 & 425.763 & 188.914 & 181.293 \\
\hline CLs (L/kg.h) & 0.155 & 0.030 & 0.054 & 0.080 & 0.100 & 0.029 & 0.095 & 0.108 & 0.067 & 0.020 & 0.124 & 0.122 \\
\hline
\end{tabular}

$\mathrm{A}(\mu \mathrm{g} / \mathrm{mL})$, Intercept of the linear equation on log transformed data; $\mathrm{B}(\mu \mathrm{g} / \mathrm{mL})$, Slope of the linear equation on log transformed data; $\mathrm{a}(/ \mathrm{h}), \mathrm{Distribution}$ rate constant; $\beta(/ \mathrm{h})$, Elimination rate constant; $\mathrm{Ka}(/ \mathrm{h})$, Absorption rate constant; Kel(/h), elimination rate constant from the central compartment; $\mathrm{T} 1 / 2 \mathrm{a}(\mathrm{h})$, Half-life of distribution; $\mathrm{T}_{1 / 2 \beta}(\mathrm{h})$, Half-life of elimination; Tmax(h), Time required to reach Cmax in the interval; $\mathrm{MRT}_{0-\mathrm{t}}(\mathrm{h})$, Mean residue time of drug in body from zero to $168 \mathrm{~h}$; $\mathrm{Cmax}(\mu \mathrm{g} / \mathrm{mL})$, Maximum concentration in the interval; $A U C_{24}(\mu \mathrm{g} / \mathrm{mL} \cdot \mathrm{h})$, Area under the drug concentration-time curve from the time zero to $24 \mathrm{~h}$; $A U C(\mu \mathrm{g} / \mathrm{mL} \cdot \mathrm{h})$,

Area under the drug concentration-time curve from the time zero to last time point; $\mathrm{CLs}(\mathrm{L} / \mathrm{kg} \cdot \mathrm{h})$, total body clearance.

\section{Pharmacokinetics of metabolite ciprofloxacin in grass carp}

Although this study was aimed to examining potential dosage regimens for enrofloxacin against a specific bacterial pathogen, the PK parameters of its major metabolite ciprofloxacin was investigated in parallel with the analysis of enrofloxacin. It was well accepted that the rate of transformation of enrofloxacin to ciprofloxacin in aquatic animals was significantly less than that in terrestrial animals [3], which suggested that enrofloxacin was mainly responsible for clinical efficacy in fish. However, the marker residue for tissues after oral dose of enrofloxacin was the sum of the enrofloxacin and ciprofloxacin residues. Although ciprofloxacin itself was forbidden to be used in aquatic species, the permitted residue level of ciprofloxacin in fish was $0.030-0.050 \mu \mathrm{g} / \mathrm{g}$ in most countries. Thus, PK parameters of ciprofloxacin would be helpful in determining a suitable withdrawal time for enrofloxacin in grass carp.

Figure 3 depicted the time course of metabolite ciprofloxacin concentrations in serum, liver, kidney, and muscle from grass carp after oral gavage of enrofloxacin at a dose of $10 \mu \mathrm{g} / \mathrm{g}, 20 \mu \mathrm{g} / \mathrm{g}$, and $30 \mu \mathrm{g} / \mathrm{g}$, respectively. In general, ciprofloxacin was detectable $0.5 \mathrm{~h}$ after drug delivery and high dose resulted a shorter time to reach $\mathrm{C}_{\text {max }}$. As expected, only a small portion of enrofloxacin was transmitted to ciprofloxacin. At the dose of $30 \mu \mathrm{g} / \mathrm{g}$ of enrofloxacin, the $C_{\max }$ of ciprofloxacin in serum, liver, muscle, and kidney was only $0.254 \mu \mathrm{g} / \mathrm{mL}$, $1.480 \mu \mathrm{g} / \mathrm{g}, 0.329 \mu \mathrm{g} / \mathrm{g}$, and $0.386 \mu \mathrm{g} / \mathrm{g}$, respectively. Similar to enrofloxacin, the time to $C_{\max }$ in muscle for ciprofloxacin was significantly longer than in serum and other tissues. For example, the $\mathrm{T}_{\max }$ for serum, liver, kidney, and muscle at the dose of $30 \mu \mathrm{g} / \mathrm{g}$ was $0.5 \mathrm{~h}, 0.5 \mathrm{~h}, 1 \mathrm{~h}$ and $4 \mathrm{~h}$, respectively.

Analyzed by Kinetica4.4, the concentration-time profiles of ciprofloxacin could be described by a one-compartment model (Table 4). The correlation coefficient exceeded 0.99 and high model criteria $(>5)$ were obtained.

Listed PK parameters were demonstrated in Table 5. By comparison of the AUC of enrofloxacin and ciprofloxacin at different dosage $(10 \mu \mathrm{g} / \mathrm{g}, 20 \mu \mathrm{g} / \mathrm{g}, 30 \mu \mathrm{g} / \mathrm{g})$, the transformation rate of enrofloxacin to ciprofloxacin in serum was determined to be $0.85 \%, 1.13 \%$ and $1.87 \%$, respectively. In liver, the rate was $4.93 \%, 6.09 \%$ and $7.59 \%$, respectively; in kidney, the rate was $1.29 \%, 1.74 \%$, and $1.88 \%$, respectively; in muscle, the rate was $1.10 \%$, $1.38 \%$, and $2.33 \%$, respectively. Although ciprofloxacin demonstrated a similar residue time $\left(\mathrm{MRT}_{0-\mathrm{t}}\right)$ than enrofloxacin, the CLs of ciprofloxacin was higher than enrofloxacin at all the three doses, which suggested that the withdrawal time could be decided according to the time to reach zero residue level of enrofloxacin since the elimination rate of ciprofloxacin was faster. 


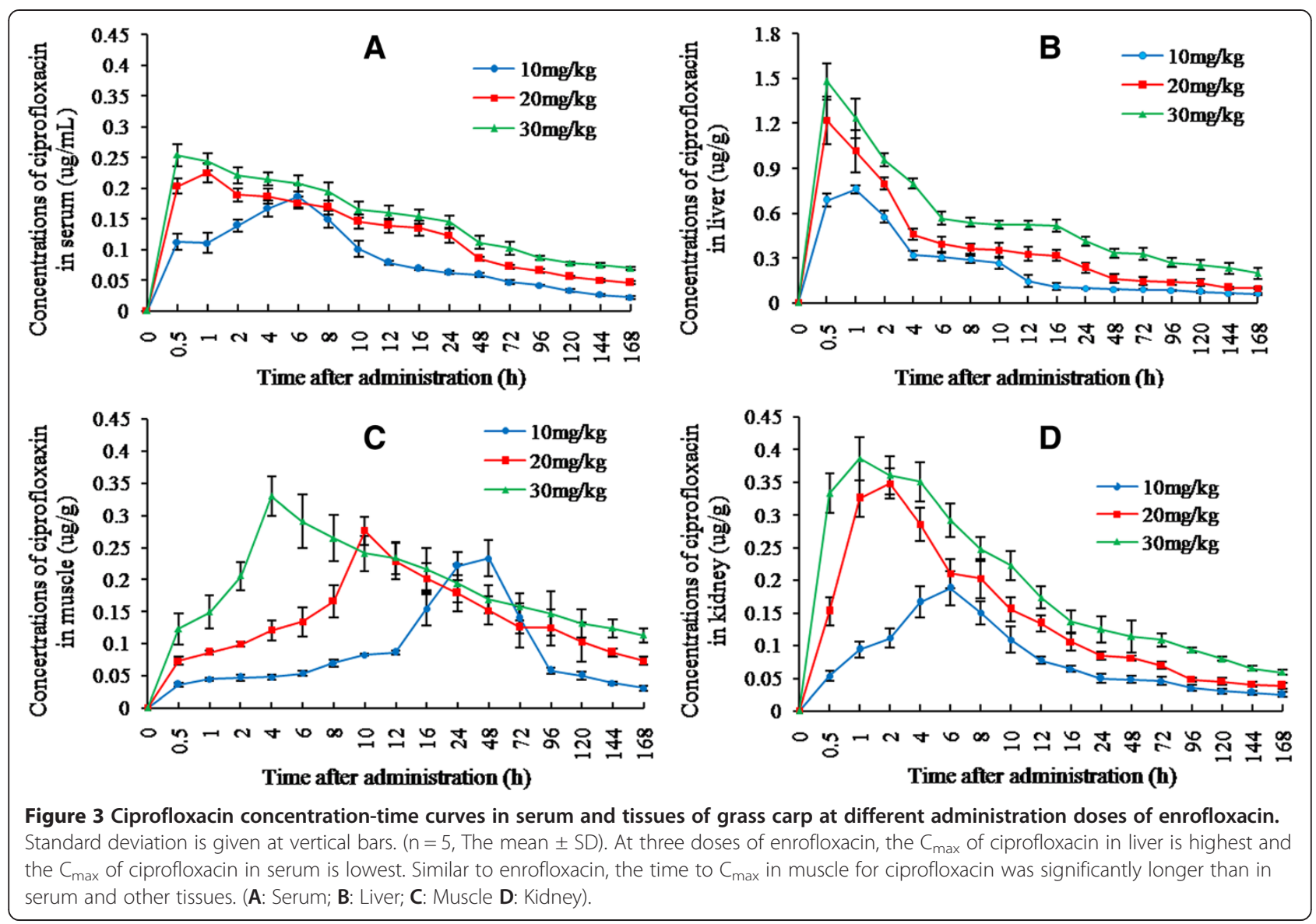

\section{Dosing guidelines of enrofloxacin based on integrated PK/PD parameters}

Overuse and misuse of antimicrobial drugs had favoured the growth of resistant organisms. Inappropriate dosage regments included misuses in dose, dosage interval, duration of treatment, route and conditions of administration. In this study, we focused on dose and dosage interval selection. Traditional PK/PD indices (AUC/MIC, T > MIC, and $\mathrm{C}_{\max } / \mathrm{MIC}$ ) have been proposed to predict the success or failure of therapy, which only considered one PD biomarker, MIC. Although positive clinical outcome might be achieved by a dosage regimen based on these indices, it didn't rule out the possibility of selecting drug-resistant mutant. Challenged by the emergence and spread of various resistance strains worldwide, the concepts of MSW and MPC provided new conceptual basis for PK/PD approaches in deciding dosing guidelines: treatments should maximize the time during which enrofloxacin cocentrations at the site of infection were above the MPC, and minimize the time during which these concentrations were in the MSW. Thus $\mathrm{T}>\mathrm{PC}$, instead of of $\mathrm{T}>\mathrm{MIC}$, was considered the most important factor in deciding dose regimens for the prevention of mutant selection. Although tissue drug concentration demonstrated difference with serum, serum concentration was more relevant in predicting antibiotic efficacy. Thus, serum PK/PD parameters were the major data that was based to draw a dosing guideline here (Table 6 and Figure 4).

In general, $\mathrm{AUC}_{24} / \mathrm{MIC}>100$ and $\mathrm{C}_{\max } / \mathrm{MIC}>8$ predicted a clinical outcome of enrofloxacin [11]. In our analysis, $\mathrm{AUC}_{24} / \mathrm{MIC}$ and $\mathrm{C}_{\max } / \mathrm{MIC}$ of enrofloxacin in serum were 51.68 and 5.68 at the dosage of $10 \mu \mathrm{g} / \mathrm{g}$, respectively; 135.17 and 11.37 at the dosage of $20 \mu \mathrm{g} / \mathrm{g}$, respectively; 180.97 and 14.30 at the dosage of $30 \mu \mathrm{g} / \mathrm{g}$, respectively (Table 6 ). The data suggested that a dosage more than $20 \mu \mathrm{g} / \mathrm{g}$ might achieve good enough therapeutic result. However, the $\mathrm{T}>\mathrm{MPC}$ for the $20 \mu \mathrm{g} / \mathrm{g}$ dosage was only $10 \mathrm{~h}$, while $\mathrm{T}>\mathrm{MPC}$ for the $30 \mu \mathrm{g} / \mathrm{g}$ dosage could reach $24 \mathrm{~h}$. To prevent selection of resistant mutant, the dosage interval for the level of $20 \mu \mathrm{g} / \mathrm{g}$ was $10 \mathrm{~h}$, which suggested a twice-daily dose. In contrast to it, once-daily dose of $30 \mu \mathrm{g} / \mathrm{g}$ was adequate for the maximum time of enrofloxacin concentration above MPC. Apparently, dosage level of $30 \mu \mathrm{g} / \mathrm{g}$ was more cost-effective. PAE of enrofloxacin at both these two dosages were 1-2 $h$ in our assay, thus PAE wouldn't significantly affect the choice of dosage interval for enrofloxacin in grass carp. 
Table 4 Best concentration-time equations of ciprofloxacin in grass carp

\begin{tabular}{lcc}
\hline Dose & Tissues & Equation \\
\hline $10 \mu \mathrm{g} / \mathrm{g}$ & Serum & $\mathrm{C}=0.119 \mathrm{e}^{-0.010 \mathrm{t}}+0.119 \mathrm{e}^{-0.078 \mathrm{t}}$ \\
& Liver & $\mathrm{C}=0.178 \mathrm{e}^{-0.008 \mathrm{t}}+0.178 \mathrm{e}^{-0.249 t}$ \\
& Muscel & $\mathrm{C}=0.048 \mathrm{e}^{-0.001 \mathrm{t}}+0.048 \mathrm{e}^{-0.171 \mathrm{t}}$ \\
& Kidney & $\mathrm{C}=0.125 \mathrm{e}^{-0.011 \mathrm{t}}+0.125 \mathrm{e}^{-0.202 \mathrm{t}}$ \\
& Serum & $\mathrm{C}=0.175 \mathrm{e}^{-0.009 \mathrm{t}}+0.175 \mathrm{e}^{-0.268 \mathrm{t}}$ \\
& Liver & $\mathrm{C}=0.451 \mathrm{e}^{-0.008 \mathrm{t}}+0.451 \mathrm{e}^{-0.222 \mathrm{t}}$ \\
& Muscel & $\mathrm{C}=0.188 \mathrm{e}^{-0.003 \mathrm{t}}+0.188 \mathrm{e}^{-0.171 \mathrm{t}}$ \\
& Kidney & $\mathrm{C}=0.222 \mathrm{e}^{-0.012 \mathrm{t}}+0.222 \mathrm{e}^{-0.214 t}$ \\
& Serum & $\mathrm{C}=0.209 \mathrm{e}^{-0.007 t}+0.209 \mathrm{e}^{-0.248 \mathrm{t}}$ \\
& Liver & $\mathrm{C}=0.710 \mathrm{e}^{-0.007 t}+0.710 \mathrm{e}^{-0.217 t}$ \\
& Muscel & $\mathrm{C}=0.260 \mathrm{e}^{-0.005 t}+0.260 \mathrm{e}^{-0.222 \mathrm{t}}$ \\
& Kidney & $\mathrm{C}=0.488 \mathrm{e}^{-0.015 t}+0.488 \mathrm{e}^{-0.211 \mathrm{t}}$ \\
\hline
\end{tabular}

Elisa $\mathrm{R}$ et al. [20] suggested that the efficacy of administering enrofloxacin at $10 \mathrm{mg} / \mathrm{kg}$ in medicated water to turkeys was evaluated by applying a PK/PD approach to the kinetic parameters obtained after oral pulsed administration and to the MIC values of avian pathogenic Escherichia coli (APEC) strains isolated from commercial turkey flocks. The results were different from ours because of different tested animal species and pathogens, more importantly due to the different MIC values. Study on PK-PD indices of enrofloxacin in Escherichia coli O78/H12 infected chickens [21] also showed that PK-PD studies should include not only AUC/MIC and Cmax/MIC estimation but also determination of MPC values, which could describe better response of bacterial strain to the used fluoroquinolones. The high dose (2.5 ml enrofloxacin/ $1 \mathrm{~L}$ drinking water) of enrofloxacin was better than low dose $(0.5 \mathrm{ml}$ enrofloxacin solution/1 $\mathrm{L}$ drinking water) for efficient eradication of bacteria.

Reasonable dosage regimen should be based on PK/PD studies and determined by practical application of the test animals. The size of the dose and dosing interval were the key indices to meet the requirement of positive clinical outcome of fish: enough time of in vivo therapeutic concentrations, no adverse effects on the body, and acceptable withdrawal period. Usually concentrationdependent antibacterial drugs, like enrofloxacin, should be delivered through once-daily dosing approach, which was crucial for higher $\mathrm{C}_{\max }$ or $\mathrm{C}_{\max } / \mathrm{MIC}$ ratio to maximize the opportunity to get the best bactericidal action and clinical effect. The fact that Gram-negative bacteria became temporarily and reversibly adaptive resistant $2 \mathrm{~h}$ after administration of antimicrobial drugs also suggested that longer dosing interval could reduce the risk for development of adaptive resistance by microorganisms [22]. Thus, Once-daily drug delivery also contributed to maximize the bacterialcidal effect of enrofloxacin by avoiding adaptive resistance.

\section{Recommended withdrawal time based on the elimination rate of enrofloxacin and ciprofloxacin}

Many countries protected consumer health from possible drug residues in fish by setting tolerable concentrations of drug residues, and surveillance agencies had been checking for compliance with the relevant directives. To ensure delivery of safe fish products to consumers, the withdrawal time of drugs must be respected [23]. It was worth to mention that the elimination rate of both enrofloxacin and

Table 5 PK parameters of ciprofloxacin in grass carp $(n=5)$

\begin{tabular}{|c|c|c|c|c|c|c|c|c|c|c|c|c|}
\hline \multirow{3}{*}{$\begin{array}{c}\text { Tissues } \\
\text { Parameter }\end{array}$} & \multicolumn{12}{|c|}{ Dose } \\
\hline & \multicolumn{4}{|c|}{$10 \mathrm{mg} / \mathrm{kg}$} & \multicolumn{4}{|c|}{$20 \mathrm{mg} / \mathrm{kg}$} & \multicolumn{4}{|c|}{$30 \mathrm{mg} / \mathrm{kg}$} \\
\hline & Serum & Liver & Muscle & Kidney & Serum & Liver & Muscle & Kidney & Serum & Liver & Muscle & Kidney \\
\hline $\mathrm{A}(\mu \mathrm{g} / \mathrm{mL})$ & 0.104 & 0.172 & 0.048 & 0.118 & 0.169 & 0.435 & 0.185 & 0.21 & 0.203 & 0.687 & 0.254 & 0.453 \\
\hline$A(/ h)$ & 0.01 & 0.008 & 0.001 & 0.011 & 0.009 & 0.008 & 0.003 & 0.012 & 0.007 & 0.007 & 0.005 & 0.015 \\
\hline $\mathrm{Ka}(/ \mathrm{h})$ & 0.078 & 0.249 & 0.171 & 0.202 & 0.268 & 0.222 & 0.171 & 0.214 & 0.248 & 0.217 & 0.222 & 0.211 \\
\hline $\mathrm{Kel}(/ \mathrm{h})$ & 0.031 & 0.027 & 0.016 & 0.019 & 0.02 & 0.028 & 0.012 & 0.022 & 0.019 & 0.025 & 0.012 & 0.023 \\
\hline$T_{1 / 2 a}(h)$ & 70.300 & 54.558 & 126.553 & 46.273 & 74.727 & 74.283 & 129.297 & 57.892 & 92.733 & 98.544 & 140.684 & 63.202 \\
\hline $\operatorname{Tmax}(\mathrm{h})$ & 6.000 & 1.000 & 48.000 & 6.000 & 1.000 & 0.500 & 10.000 & 2.000 & 0.500 & 0.500 & 4.000 & 1.000 \\
\hline $\operatorname{Cmax}(\mu \mathrm{g} / \mathrm{mL})$ & 0.187 & 0.759 & 0.233 & 0.188 & 0.225 & 1.219 & 0.276 & 0.348 & 0.254 & 1.480 & 0.329 & 0.386 \\
\hline$M R T_{0-t}(h)$ & 61.453 & 61.61 & 60.652 & 59.982 & 64.912 & 62.200 & 71.581 & 63.192 & 69.093 & 67.674 & 73.703 & 64.946 \\
\hline $\mathrm{A} \cup C(\mu \mathrm{g} / \mathrm{mL} \cdot h)$ & 8.392 & 17.09 & 2.704 & 7.633 & 13.516 & 29.941 & 21.380 & 12.166 & 17.665 & 55.732 & 26.675 & 18.329 \\
\hline$C L s(L / k g \cdot h)$ & 0.920 & 0.429 & 17.893 & 0.913 & 1.078 & 0.214 & 0.272 & 0.572 & 1.072 & 0.102 & 0.210 & 0.331 \\
\hline
\end{tabular}

$\mathrm{A}(\mu \mathrm{g} / \mathrm{mL})$, Intercept of the linear equation on log transformed data; $\mathrm{a}(/ \mathrm{h})$, Distribution rate constant; $\mathrm{Ka}(/ \mathrm{h})$, Absorption rate constant; Kel(/h), elimination rate constant from the central compartment; $\mathrm{T}_{1 / 2 a}(\mathrm{~h})$, Half-life of distribution; Tmax(h), Time required to reach $\mathrm{Cmax}$ in the interval; $\mathrm{Cmax}(\mu \mathrm{g} / \mathrm{mL})$, Maximum concentration in the interval; $\mathrm{MRT}_{0-\mathrm{t}}(\mathrm{h})$, Mean residue time of drug in body from zero to $168 \mathrm{~h} ; \mathrm{AUC}(\mu \mathrm{g} / \mathrm{mL} \cdot \mathrm{h})$, Area under the drug concentration-time curve from the time zero to last time point; $\mathrm{CLs}(\mathrm{L} / \mathrm{kg} \cdot \mathrm{h})$, total body clearance. 
Table 6 Serum PK-PD parameters

\begin{tabular}{ccccc}
\hline Dosage $(\boldsymbol{\mu g} / \mathbf{g})$ & Cmax/MIC & AUC $_{\mathbf{2 4}} / \mathbf{M I C}$ & $\mathbf{M P C}(\mathbf{u g} / \mathbf{m l})$ & $\mathbf{M S W}(\mathbf{u g} / \mathbf{m l})$ \\
\hline 10 & 5.68 & 51.68 & 3.0 & $0.5 \sim 3.0$ \\
20 & 11.37 & 135.17 & 3.0 & $0.5 \sim 3.0$ \\
30 & 14.30 & 180.97 & 3.0 & $0.5 \sim 3.0$ \\
\hline
\end{tabular}

ciprofloxacin was slowest in muscle. Thus, the muscle residue levels apparently represented the length of withdrawal period. From the concentration-time equations of both enrofloxacin and ciprofloxacin at a dosage of $30 \mu \mathrm{g} / \mathrm{g}$ in muscle (Table 2 and 4), it would take at least $32 \mathrm{~d}$ for enrofloxacin (32 d) and ciprofloxacin (15 d) to be depleted to a permitted residue level of $30 \mu \mathrm{g} / \mathrm{kg}$. According to the present data, the proposed withdrawal period in grass carp should not be less than $32 \mathrm{~d}$. Both enrofloxacin and ciprofloxacin levels reached to the detection limit of our HPLC system at $32 \mathrm{~d}$ after the dosage of $30 \mu \mathrm{g} / \mathrm{g}$, and became undetectable at $37 \mathrm{~d}$ post drug delivery. This result partially validated our PK/PD parameters. However, the present study didn't consider the effect of continuous drug delivery (generally 3-7 d for bacterial disease) on the elimination rate of enrofloxacin or ciprofloxacin, a withdrawal period of more than $32 \mathrm{~d}$ might be expected.

\section{Conclusions}

The PD parameters (MIC, MPC, and MSW) of A. hydrophila AH10, isolated from grass carp Ctenopharyngodon idella, were characterized. The PK parameters in serum and tissues (liver, kidney, and muscle) of enrofloxacin following a single oral treatment in grass carp Ctenopharyngodon idella at three different dosage levels $(10,20$, and $30 \mu \mathrm{g} / \mathrm{g})$ were investigated. Integrated PK/PD parameters (AUC/MIC, $\mathrm{C}_{\max } / \mathrm{MIC}$, and $\mathrm{T}>\mathrm{MPC}$ ) suggested that once-daily dosage of $30 \mu \mathrm{g} / \mathrm{g}$ predicted a positive clinical outcome and minimize the selection of drug-resistant AH10 mutant. Our approach in combining

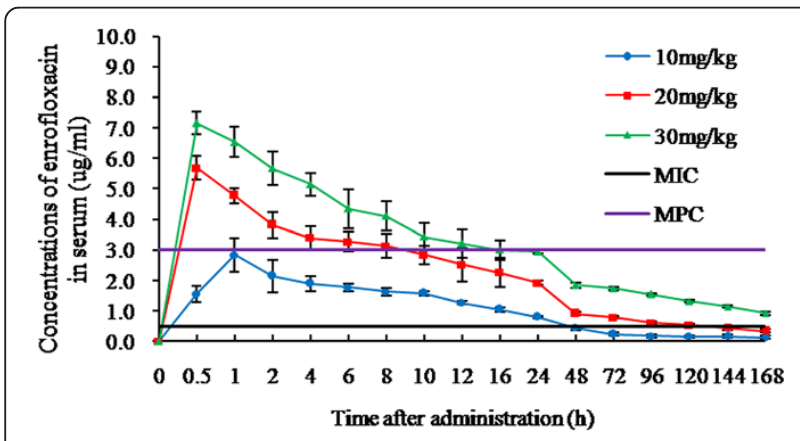

Figure 4 Dtermination of T>MPC at the indicated dosing levels ( $\mathbf{n}=\mathbf{5}$, The mean \pm SD). The T>MPC for the $10 \mu \mathrm{g} / \mathrm{g}$ dosage was $0 \mathrm{~h}$, the T>MPC for the $20 \mu \mathrm{g} / \mathrm{g}$ dosage was $10 \mathrm{~h}$, while T>MPC for the $30 \mu \mathrm{g} / \mathrm{g}$ dosage could reach $24 \mathrm{~h}$.
PK data with PD parameters (including MPC and MSW) was the new effort in aquaculture to face the challenge of drug resistance by drawing a specific dosage guideline of antibiotics.

\section{Methods}

Fish

All animal procedures were reviewed and approved by the Institutional Animal Care and Use Committee at Shanghai Ocean University. Animal care and experimentation were undertaken in accordance with Ocean University of Shanghai animal care guidelines. 500 grass carp Ctenopharyngodon idellas (body weight of around $200 \mathrm{~g}$ ) were obtained from a fish hatchery in Shanghai, China and maintained in 600-L fiberglass tanks with circulating, filtered and well-aerated tap water at $22.0 \pm 1.0^{\circ} \mathrm{C}$ under a $12: 12 \mathrm{~h}$ day:night cycle and were reared under normoxia $\left(7.0 \pm 0.2 \mathrm{mg} \mathrm{O}_{2} / \mathrm{L}\right)$ for 2 week prior to experimentation, and with no history of fluoroquinolone treatment. The fish were being fed daily with artificial feed (Charoen Pokphand Group).

\section{Chemicals}

Enrofloxacin and ciprofloxacin powder standards were obtained from Sigma (St Louis, MO, USA). Prototype enrofloxacin $(\geq 99 \%)$ was supplied from Zhejiang Xinchang Pharmaceutical Co., Ltd. Organic solvents used in this study were of HPLC grade (Sigma-Aldrich, China). other chemicals were analytical grade (Dingguo Biotech, Beijing); Mueller-Hinton Broth (MHB) and Mueller-Hinton Agar (MHA) was supplied from Sinopharm Chemical Reagent Beijing Co., Ltd.

\section{Drug administration}

In oral gavages, the fish were divided into three groups (300, 100/group), fish were given a dose of $10,20,30 \mu \mathrm{g} / \mathrm{g}$ body weight individually. Enrofloxacin solution $(60 \mathrm{~g} / \mathrm{L})$ was forced into the stomach of the grass carp using a 1-ml syringe fitted with an obtuse $7^{\#}$ gauge needle. (225 fish were killed after the end of the experiment.)

\section{Sample collection}

Five live fish were sampled at intervals ranging from $0.5-168 \mathrm{~h}$ after the administration. Fish were anesthetized with 2-phenoxyethanol $(2 \mathrm{~mL} / \mathrm{L})$ before handling. One milliliter of blood was drawn into heparinized syringes from the caudal artery. Blood samples were centrifuged at $10000 \times \mathrm{g}$ for $10 \mathrm{~min}$, the serum was then collected and stored at $-20^{\circ} \mathrm{C}$. Fish were than euthanized by concussion. Liver, kidney, and muscle tissues were taken and frozen at $-20^{\circ} \mathrm{C}$. 


\section{Analytical methods}

\section{HPLC (high performance liquid chromatography)}

Serum and tissue concentrations of enrofloxacin and ciprofloxacin were assayed by HPLC. HPLC analysis was performed with Agilent 1100 consisted of double pump, auto-injector, column temperature tank, and fluorescence detector that was set at 280 and $450 \mathrm{~nm}$ as excitation and emission wavelengths, respectively. The mobile phase consisted of acetonitrile and 0.01 $\mathrm{M}$ tetrabutylammonium bromide solution (5:95 V/V). The $\mathrm{pH}$ of tetrabutylammonium bromide solution was adjusted to 3.1 by phosphoric acid. Zorbax SB C-18 column $(4.6 \times 150 \mathrm{~mm})$ was used for the separation. The flow rate was $1.0 \mathrm{ml} / \mathrm{min}$. The column temperature was controlled at $40^{\circ} \mathrm{C}$. External standards were enrofloxacin and ciprofloxacin (Sigma-Aldrich, China).

Extraction of the compounds from serum and tissue samples were achieved with 90\% acidified acetonitrile (containing 1\% acetic acid) and 10\% $0.15 \mathrm{M}$ hydrochloric acid according to a modified protocol [3]. Recovery and precision of the method, as well as the standard calibration curves, were determined by a routine method [24]. For both enrofloxacin and ciprofloxacin, the assay was linear between 0.01 and $10 \mu \mathrm{g} / \mathrm{ml}$ or $\mu \mathrm{g} / \mathrm{mg}$.

\section{$\mathrm{LD}_{50}$}

In order to estimate the median lethal dose $50 \%\left(\mathrm{LD}_{50}\right)$ of isolate $\mathrm{AH} 10$, duplicated groups of grass carp of $100-120 \mathrm{~g}$ (50, 10/group) were injected intraperitoneally with $200 \mu \mathrm{l}$ of serial dilutions of isolate $\mathrm{AH} 10$, from $1 \times 10^{3}$ to $1 \times 10^{8} \mathrm{CFU} / \mathrm{ml}$. Control groups were injected with PBS. Mortalities were recorded for 7 days. (35 fish were killed after the end of the experiment.)

\section{MIC}

Minimum inhibitory concentration (MIC) was determined by the double-tube method [25,26]. Briefly, $1 \mathrm{ml}$ of $128 \mu \mathrm{g} / \mathrm{mL}$ enrofloxacin was dissolved in $1 \mathrm{ml}$ fresh Mueller-Hinton Broth (MHB) media in tube \#1. Subsequently, $1 \mathrm{ml}$ of culture from tube \#1 was removed and added to tube \#2 containing $1 \mathrm{ml} \mathrm{MHB}$ media. The series of dilutions was carried out for a total of 12 tubes. All 12 testing tubes along with 2 control tubes were separately inoculated with $20 \mu \mathrm{L} \quad\left(10^{6} \mathrm{CFU} / \mathrm{mL}\right)$ isolate $\mathrm{AH} 10$ suspension and incubated in a $30^{\circ} \mathrm{C}$ (the optimum growth temperature of A. hydrophila strain is $28 \sim 30^{\circ} \mathrm{C}$ ) incubator for $24 \mathrm{~h}$. The lowest drug concentration among tubes with no bacterial growth would be the drug's minimum inhibitory concentration (MIC). This experiment was performed in 3 replicates. Reference strain A. hydrophila strain ATCC 7966 (store in Key Laboratory of Freshwater Fishery Germplasm Resources, Shanghai) was used for quality control.

\section{MPC and MSW}

The mutant prevention concentration (MPC) indicated the susceptibility of the small number of resistant mutant bacterial present before any drug treatment. The MPC was determined by methods described by Frederique Pasguali et al. [27]. Briefly, isolate AH10 was cultured in MHB media for $24 \mathrm{~h}$. Then this cultured suspension was centrifuged (at $4000 \times \mathrm{g}$ for $10 \mathrm{~min}$ ) and used MHB media to resuspend the isolate $\mathrm{AH} 10$ to a concentration of $10^{10} \mathrm{CFU} / \mathrm{mL}$. $300 \mu \mathrm{L}$ isolate AH10 suspension, containing more than $10^{10} \mathrm{CFU} / \mathrm{mL}$, were plated on each of four Mueller-Hinton Agar (MHA) plates supplemented with either enrofloxacin at concentration equal to $1 \times$, $2 \times, 3 \times, 4 \times, 5 \times, 6 \times, 7 \times, 8 \times, 9 \times, 10 \times$ MIC. Plates were incubated at $30^{\circ} \mathrm{C}$ for $48 \mathrm{~h}$, colonies counted and incubated again for an additional $72 \mathrm{~h}$. The MPC was recorded as the lowest drug concentration preventing the emergence of any mutant after $48 \mathrm{~h}$ and $120 \mathrm{~h}$ incubation. Each experiment was carried out three times.

\section{PAE}

Post antibiotic effect (PAE) was classically defined as the period of bacterial growth suppression that persisted after a limited exposure of organisms to antimicrobials. In establishing dosing schedule, duration of PAE should be added to the effective therapeutic period, which was drawn from the time window with a concentration more than MIC or MPC. The presence of PAE was determined by methods described by Gudmundsson [28]. To assess PAE, isolate AH10 $\left(2.5 \times 10^{3} \mathrm{CFU} / \mathrm{ml}\right)$ was exposed to enrofloxacin at $2-8 \mathrm{MIC}$ for $1 \mathrm{~h}$. At the end of the exposure period, the antibiotic was removed by diluting $1: 10^{3}$ into the same prewarmed medium. For quantification of the PAE, viable counts were determined before and after drug exposure, and then hourly for $12 \mathrm{~h}$. PAE was expressed in hour and determined by the formula PAE $=\mathrm{T}-\mathrm{C}$. $\mathrm{T}$ represented the time for the drug-treated inoculum to amplify to a concentration of 10 folds of the starting point, $C$ represented the time for the untreated control culture to increase to 10 folds of its starting point.

\section{Pharmacokinetic analysis}

The computer program Kinetica4.4 (Thermo Fisher Scientific) was used to derive pharmacokinetic values, which described the drug concentration-time data very well. The pharmacokinetic parameters were analyzed based on statistical moment theory for the serum and tissues concentration-time data of enrofloxacin and its active metabolite ciprofloxacin. The following PK parameters were determined and analyzed: $C_{\max }$ (peak concentration), $\mathrm{T}_{1 / 2 \alpha}$ (half-life of the absorption rate constant), $\mathrm{T}_{1 / 2 \beta}$ (half-life of the elimination rate constant), $\mathrm{AUC}_{24}$ (area under the concentration-time curve from 
time zero to $24 \mathrm{~h}$ ), $\mathrm{MRT}_{0-\mathrm{t}}$ (mean residue time in body from zero to $168 \mathrm{~h}$ ), and CLs (total body clearance).

\section{Pharmacodynamics analysis}

Due to the determined low transformation rate (less than $5 \%$ ) of enrofloxacin to ciprofloxacin in this study, the antibiotic function of ciprofloxacin was found insignificant as a metabolite. Pharmacodynamics analysis was only performed on enrofloxacin. By integrating experimental pharmacokinetic data and in vitro activities of enrofloxacin on isolate AH10, optimal microbiological outcomes were most likely predicted by $\mathrm{C}_{\max } / \mathrm{MIC}$, AUC/MIC, and T>MPC.

\section{Competing interests}

The authors declare that they have no competing interests.

\section{Authors' contributions}

LJX and LQL conceived the study, participated in its design and coordination, data acquisition and analysis, and manuscript elaboration. HW participated in data acquisition and carried out the Pharmacokinetic analysis. XLY participated in the study design and coordination, and helped with the interpretation of data. All authors read and approved final manuscript.

\section{Acknowledgements}

This work is supported by Special Fund for China Agro-scientific Research in the Public Interest (No. 201203085), the earmarked fund for China Agriculture Research System (CARS-46-12) and First-class Discipline of Fish and Fishery Sciences of Shanghai Ocean University.

Received: 18 January 2013 Accepted: 19 June 2013 Published: 25 June 2013

\section{References}

1. Brown SA: Fluoroquinolones in animal health. J Vet Pharmacol Ther 1996, 19:1-14.

2. McKinnon PS, Davis SL: Pharmacokinetic and pharmacodynamic issues in the treatment of bacterial infectious diseases. Eur J Clin Microbiol 2004, 23:271-288.

3. Fang W, Zhou S, Yu H, Hu L, Zhou K, Liang S: Pharmacokinetics and tissue distribution of enrofloxacin and its metabolite ciprofloxacin in Scylla serrata following oral gavage at two salinities. Aquaculture 2007, 272:180-187.

4. Plumb JA, Sheifinger CC, Shryock TR, Goldsby T: Susceptibility of Six bacterial pathogens of channel catfish to Six antibiotics. J Aquat Anim Health 1995, 7:211-217.

5. Liu F, Li J, Fu J, Shen Y, Xu X: Two novel homologs of simple C-type lectin in grass carp (Ctenopharyngodon idellus): potential role in immune response to bacteria. Fish Shellfish Immunol 2011, 31:765-773.

6. Li X, Wu H, Zhang M, Liang S, Xiao J, Wang Q, Liu Q, Zhang Y: Secreted glyceraldehyde-3-phosphate dehydrogenase as a broad spectrum vaccine candidate against microbial infection in aquaculture. Lett Appl Microbiol 2012, 54:1-9.

7. Zhang D, Li A, Xie J, Ji C: In vitro antibacterial effect of berberine hydrochloride and enrofloxacin to fish pathogenic bacteria. Aquac Res 2010, 41:1095-1100.

8. Olofsson SK, Cars O: Optimizing drug exposure to minimize selection of antibiotic resistance. Clin Infect Dis 2007, 45(Suppl 2):129-136.

9. Alderman DJ, Hastings TS: Antibiotic use in aquaculture: development of antibiotic resistance - potential for consumer health risks. Int J Food Sci Tech 1998, 33:139-155.

10. Alcaide E, Blasco MD, Esteve $C$ : Mechanisms of quinolone resistance in Aeromonas species isolated from humans, water and eels. Res Microbiol 2010, 161:40-45

11. Turnidge J: Pharmacokinetics and pharmacodynamics of fluoroquinolones. Drugs 1999, 58(Suppl 2):29-36.
12. Caron WP, Mousa SA: Prevention strategies for antimicrobial resistance: a systematic review of the literature. Infect Drug Resist 2010, 3:25-33.

13. Liu KY, Wang KY: Study and practice on enrofloxacin in fishery. Chinese Vet Drug 2004, 38(suppl 10):32-34.

14. Roxana B-H, Anabel A, Noemi B, Jesus LR, Maria JF: Comparison of phenotypical and genetic identification of Aeromonas strains isolated from diseased fish. System App/ Microbiol 2010, 3(suppl 33):149-153.

15. Giraud E, Baucheron S, Cloeckaert A: Resistance to fluoroquinolones in Salmonella: emerging mechanisms and resistance prevention strategies. Microbes Infect 2006, 8:1937-1944.

16. Mckellar QA, Sanchez BSF, Jones DG: Pharmacokinetic/pharmacodynamic relationships of antimicrobial drugs used in veterinary medicine. J Vet Pharmacol Ther 2004, 27:503-514.

17. Carbone M, Pennisi MG, Masucci M, Sarro AD, Giannone M, Fera MT: Activity and postantibioticeffect of marbofloxacin, enrofloxacin, difloxacin and ciprofloxacin against feline Bordetella bronchiseptica isolates. Vet Microbiol 2001, 81:79-84.

18. Plakas SM, Said KRE, Musser SM: Pharmacokinetics, tissue distribution, and metabolism of flumequine in channel catfish (Ictalurus punctatus). Aquaculture 2000, 187:1-14.

19. Samuelsen OB: Pharmacokinetics of quinolones in fish: a review. Aquaculture 2006, 255:55-75.

20. Elisa R, Lorena L, Davide G, Pettra C, Giovanni O, Vincenzo DL, Clara M: Approved medication of water with enrofloxacin to treat turkey colibacillosis: Assessment of efficacy using a PK/PD approach. Vet Microbiol 2012, 161:206-212.

21. Aneliya H, Valentina U, Mihni L, Vladimir P, Lubomir L: Pharmacikineticpharmacodynamic indices of enrofloxacin in Escherichia coli O78/H12 infected chickens. Food Chem Toxic 2011, 49:1530-1536.

22. Parra-Sanchez A, Lugo J, Boothe DM, Gaughan EM, Hanson RR, Duran S, Belknap JK: Pharmacokinetics and pharmacodynamics of enrofloxacin and a low dose of amikacin administered via regional intravenous limb perfusion in standing horses. Am J Vet Res 2006, 67:1687-1695.

23. Martin BS, Cornejo J, Lapierre L, Iragüen D, Pérez F, Hidalgo H, Andre F: Withdrawal time of four pharmaceutical formulations of enrofloxacin in poultry according to different maximum residues limits. J Vet Pharmacol Ther 2010, 33:246-251.

24. Tang J, Yang X, Zheng Z, Yu W, Hu K, Yu H: Pharmacokinetics and the active metabolite of enrofloxacin in Chinese mitten-handed crab (Eriocheir sinensis). Aquaculture 2006, 260:69-76.

25. Clinical and Laboratory Standards Institute: Performance Standards for Antimicrobial Disk and Dilution Susceptibility Test for Bacteria Isolated from Animals; Approved Standard-Third Edition M31-A3. Wayne, PA, USA: CLSI; 2008.

26. Su ZX, Xiao H, Chen LH: In vitro antibacterial effect of Chinese herbal medicine against Aeromomonas hydrophila. InformaTech Agric Engineer 2012, 134:233-239.

27. Frederique $P$, Gerardo M: Mutant prevention concentration of ciprofloxacin and enrofloxacin against Escherichia coli, Salmonella typhimurium and Pseudomonas aeruginosa. Vet Microbiol 2007, 119:304-310.

28. Gudmundsson S, Vogelman B, Craig WA: The in-vivo postantibiotic effect of imipenem and other new antimicrobials. J Antimicrob Chemother 1986, 18(Suppl E):67-73.

\section{doi:10.1186/1746-6148-9-126}

Cite this article as: Xu et al.: Integrated pharmacokinetics/

pharmacodynamics parameters-based dosing guidelines of enrofloxacin in grass carp Ctenopharyngodon idella to minimize selection of drug resistance. BMC Veterinary Research 2013 9:126. 